\title{
Etujen puolustaja, ammatin määrittäjä
}

\section{Kai Häggman, Kivelle perustettu. Suomen kirjailijaliitto 1897-2017. Helsinki, Otava 2017,544 s.}

Suomen kirjailijaliitto julkaisi 120-vuotishistoriansa Otavan kustantamana ja Kai Häggmanin kirjoittamana reilu vuosi sitten. Ainakin huhuissa on ollut tiedossa, että tällainen historiatutkimus on ollut hankkeilla jo vuosikymmeniä, milloin kenenkin tekemänä. Aina vain kohtalo on päättänyt toisin. Vuosi sitten, Aleksis Kiven päivänä 2017, teos sitten ilmestyi ja varsin nopeasti tehtynä. Teoksen saatesanoissa Kai Häggman kertoo aloittaneensa työnsä kirjailijaliiton historian parissa kesällä 2014. Kivelle perustettu. Suomen kirjailijaliitto 1897-2017 valmistui kesäkuussa 2017. Kolmessa vuodessa 544 sivua, 120 vuotta ja valtava määrä arkistoaineiston analyyseja on mittava urakka suoritettavaksi. Häggman on selvinnyt siitä vakuuttavasti.

Historioitsija Häggmanin työtä on mitä ilmeisemmin helpottanut se, että hän on muissa töissään, muun muassa kirjoittamissaan WSOY:n (2001, 2003), suomalaisen kustannustoiminnan ja kirjamyynnin (2008) sekä Suomalaisen Kirjallisuuden Seuran (2012, 2015) laajoissa historioissa, kahlannut jokseenkin samaa aikakautta ristiin rastiin. Tämä ei tietenkään heikennä työn arvoa vaan pikemminkin tuo luotettavuutta tutkimuksen asiasisältöön ja kontekstin hallintaan. Toinen on sitten se kysymys, että alkaako suomalainen kulttuurihistoria ja erityisesti kirjallisuusinstituution historia näyttäytyä erityisen häggmannilaiselta, kun siitä on kirjoittanut 2000-luvun aikana yksi ja sama mies? Tähän kysymykseen vastaan tämän kirjoituksen lopussa.

Kivelle perustettu on kronikka sanan varsinaisessa merkityksessä. Häggman on valinnut käsittelyjärjestykseksi kronologian, lineaarisen historiakuvan ja tarinajärjestyksen, jossa edetään alusta loppuun, esihistoriasta nykyhetkeen, 1890-luvulta kuvaan liiton 120-vuotisjuhlasta 20.5.2017. Liikkeellelähtö on esihistoriassa nimenomaan siksi, että Häggman ei aloita 22.5.1897 hotelli Kämpissä pidetystä Kirjailijayhdistyksen säännöt hyväksyneestä kokouksesta, jossa Kirjailijaliiton voidaan katsoa perustetun. Hänen lähtökohtanaan on yksi aikansa tunnetuin, luetuin ja suosituin suomalainen kirjailija, kouluja käymätön valtiopäivämies Pietari Päivärinta. Jo keväällä 1891, kuusi vuotta ennen Kämpin kokousta, Päivärinta piti valtiopäivien istunnossa paheksuvan puheen siitä, kuinka "kruunu antoi jalostuspalkintoja jopa ansioituneille kilpahevosille, lehmille, lampaille ja sioille" ja kuinka valtio tuki muita taiteilijoita mutta ei kirjailijoita. 
Suomen kirjailijaliiton sittemmin ensimmäisen kunniajäsenen Päivärinnan puheen olennainen sisältö painottui valtiovallan ja kirjailijoiden vaikeaan suhteeseen: siihen, että valtiovalta ei riittävällä tavalla tukenut kirjailijoiden elinoloja ja ammatin toteuttamista. Päivärinnalle kirjailijan työ niin henkilökohtaisena kutsumuksenaan kuin yleisemminkin määriteltynä oli ennen muuta kansansivistäjän ja kansakunnanrakentajan työtä. Ilmeisenä snellmanilaisen kirjallisuuspolitiikan jalkauttajana Päivärinta puhui pitkällä jatkumolla ja A. Kiven kohtalon tarjoaman esimerkin voimalla. Häggman purkaa teoksensa preludissa, sen ensimmäisessä luvussa, koko teoksensa teemavarannon näkyviin. Sen lisäksi, että Kirjailijaliiton kirjailijan ammattia määrittävä ja sosiaalista asemaa puolustava tehtävä konkretisoituu Päivärinnan persoonassa, nostaa Häggman yksittäistapausten kautta esiin myös ne tekijät, jotka komplisoivat ja tulehduttivat kirjailijoiden ja valtiovallan välisiä suhteita. Muun muassa Juhani Ahon vuonna 1890 ilmestynyt romaani Yksin herätti valtiopäivien keskustelijoissa pahennusta ja paheksuntaa, varsinkin kun kirjailija oli saanut valtiopäiviltä rahallista tukea Pariisin matkaansa varten. Moraalittomaksi koettu prostituutiokuvaus johti siihen, että valtiovallan taloudellinen tuki kirjailijoille tyrmättiin kyseisillä valtiopäivillä täysin.

Noilla vuoden 1891 valtiopäivillä kiteytyi kaksinainen näkemys kirjailijan ammatista. Yhtäällä olivat valtion suojelukseen kuuluvat Päivärinnan tarkoittamat pyyteettömät, vakavamieliset kansanvalistajat ja sivistyksen rakentajat, toisaalla konservatiivien katsannosta kurittomat kauhukakarat. Näistä kahdesta toisiaan korvilleen lyövästä teemasta näyttäisi muotoutuneen Häggmanin Kirjailijaliiton historiaa kantava dynamiikka. Tätä jäsennystä korostavat Häggmanin kekseliä̈t väliotsikot: vuosisadan vaihdetta, sitä ensimmäistä, kuvastavat otsikot "Kappelista Kämpin kautta Suomalaiselle Klubille" ja "Paljon puhetta, jonkin verran villoja". Vuosisadan alkua, jolloin liitto vaihtoi nimensä Kaunokirjailijaliitosta Suomen Kirjailijaliitoksi, puolestaan luonnehtivat otsikot "Uusi nimi, vanhat ongelmat" ja "Kioskikirjallisuuden maihinnousu". Hurvittelevia kauhukakaroita ja heidän ympärillään leijuvaa skandaalin käryä ilmentää 1920-lukuun liittyvä otsikko "Minna Craucherin dubletti ja Unto Seppäsen kanala". Niin sanottua toisen tasavallan Kirjailijaliittoa jäsentää vahva poliittinen jakautuneisuus, joka tuotti myös kirjallisuuspoliittisia rintamia. Yhtä lailla aikakauteen kuuluvat eettismoraaliset dilemmat, joihin Häggman viittaa otsikolla "Siveys vai sananvapaus" sekä "Kirjasodat ja Kirjailijaliitto".

On myönnettävä, että nykyhetkeä lähestyessään teoksen otsikointi muuttuu arkisemmaksi ja vähemmän kiinnostusta herättäväksi. Enkä usko, että syynä on historioitsija Häggmanin mielikuvituksen kuihtuminen. On pahoin pelättävissä, että aikakaudet muuttuvat tylsemmiksi, kirjallisuus saa rinnalleen dramaattisempia kilpailijoita ja puheenaiheita. Samaan aikaan tosi-tv:n ja someraivon parkitsemassa ja kovettamassa maailmassa kirjallisuus ei vain yksinkertaisesti toimi enää radikaalin provokaation välineenä, eikä oikein mikään muukaan. Liiton tilaa näyttäisi kuvaavan sellaiset otsikot kuin "Käykää 
oma taistelunne" tai ironisesti Paavolaisen 1930-luvun alun siivousmetaforaan viittaava sitaattiotsikko "Kirjailijaliiton 100-vuotisjuhlan aattona on huolehdittava, että omat nurkat ovat puhtaat". Sitaatti on liittoa varsin autoritaarisesti ja pitkään johtaneen Jarkko Laineen puheista. Häggmanin teoksen kontekstissa se on myös ymmärrettävissä eräänlaisena kannanottona aikakauden yleiseen eetoksen, omien etujen ajamiseen, kulissit kuntoon -mentaliteettiin ja yleisen kapitalisoitumisen mukanaan tuomaan individualismiin. Kirjallisessa elämässä se tarkoitti muun muassa kirjoitustyötä tekevien yhteisen etupolitiikan murenemista liittojen keskinäiseen kinasteluun apurahoista. Se mikä tässä varsinaisen aatteensa menettäneessä kulttuurijärjestön touhussa on enää mielenkiintoista, on se perustava työ, jota liitto tai liitot tekevät kirjailijan ammattia määrittäessään. Omakustanteiden, halpakustanteiden, kertakustanteiden ja muiden kustanteiden luvattuna aikakautena kirjailijan ammattinimikkeen ottaminen ja käyttäminen on helpompaa kuin koskaan. Se kun ei ole weberiläinen Schliessung, sosiaalinen sulkeuma, niin kuin monet muut taiteilijaammatit ovat. Oikeastaan vain liittojen jäsenyys, ja sitä määrittävät kriteerit muodostavat sen repeilevän, seitinohuen rajan amatöörien ja ammattilaisten välille tämän päivän kirjallisessa elämässä.

Niin, se vastaus kysymykseen suomalaisen kirjallisuusinstituution historian mahdollisesta monoliittisuudesta: kyllä vähän. Kai Häggman on kirjoittanut niin monta historiaa kirjallisesta elämästä, että alkaa näyttää, että yksi tulkintatapa hallitsee tämän hetkistä tulkintaa suomalaisen kirjallisen elämän synnystä, kehityksestä, kamppailuista ja 2000-luvusta. Mutta ei se huono tulkinta ja kuva ole. Häggmanilla on kaikissa kirjoittamissaan historioissaan ollut taito tasapainoilla paikoin tylsänkin aineiston ja äärimmäisen mielenkiintoisten detaljien välillä. Samalla kun hän luo yleistä kokokuvaa, hän värittää sitä intiimeillä yksittäisillä anekdooteilla. Näin Häggman on historian dramaturgi. Kokonaiskuvaa luodessaan hän jäsentää tutkimuksissaan pitkää historiaa turvallisilla, totuudeksi muodostuneilla periodeilla, jotka jäsentävät kokonaisuuden kahdeksaan päälukuun. Muun muassa sodan jälkeinen aika lohkoutuu "toiseksi tasavallaksi" (1945-1968), "hyvinvointivaltioksi" (1968-1990) ja "markkinavoimien aikakaudeksi" (1991-2017). Hyväksi havaittu ja toimiva, mutta konsensuaalinen tapa jäsentää suomalaiskansallista lähimenneisyyttä. Vaikka se ei ehkä juhlahistoriikkeihin kuuluu, tässä alkaa kaivata historian kirjoitukseen vähän vaarantuntua, täysin uudenlaisen paradigman ja menneisyyskonseptin kokeilua.

Edellistä ei pidä lukea moitteena Kai Häggmanin Kivelle perustettu -teosta kohtaan. Se on juhlakirja eikä kokeilukenttä. Ja rehellisyyden nimessä on todettava, että Häggman kuljettaa tutkimuksessaan paljon laveammin eri teemoja kuin mitä tässä on mahdollista läpikäydä. Historia muun muassa maalaa kuin ohimennen muotokuvia eri aikakausin puheenjohtajista, tuo näkyväksi kirjailijoiden toimintaverkon kansainvälistymisen, luotaa poliittiset rintamalinjat ja kirjailijoiden suhteet eri työnantajiinsa kuten kustantamoihin ja mediaan. 
Ennen muuta Kivelle perustettu on objektiivinen selvitys kirjailijan ammatin muuttuvista ja muuttumattomista piirteistä. Samalla se on, juhlakirjaluonteensa mukaisesti, kunnianosoitus ammattikunnalle, jonka työ on edelleen painavaa ja arvokasta. Kai Häggman lopettaa teoksensa hienosti ottaessaan esiin nykyisen Suomen Kirjailijaliiton kaksi nuorinta jäsentä Pajtim Statovicin ja Daniil Kozlovin ja toteaa heistä: "He tekevät sitä, mitä kirjailijat ovat aina tehneet."

Risto Turunen 